\title{
Structural orientation and social agency in South Africa: state, race, higher education and transformation
}

\author{
Lionel Thaver \\ Department of Anthropology and Sociology, University of the Western Cape \\ E-mail address: lthaver@uwc.ac.za \\ and \\ Beverley Thaver \\ Faculty of Education, University of the Western Cape \\ E-mail address:bthaver@uwc.ac.za
}

\begin{abstract}
:
We have taken as our brief and context the latest upsurge in incidents of a racist nature in certain higher education institutions in South Africa. What we contribute to thinking on the subject is Goldberg's (2002) theoretical framework in which he focuses on the emergence, formation, existence and transformation of racial formations as constitutive of social life. In the South African context we apply this framework and its understanding of racial traditions to bigher education in order to reveal the shifts across the social formations of segregation, apartheid and constitutional democracy. Our central argument is that Goldberg's concept of racial naturalist and racial historicist traditions of social agency when applied to higher education institutions disclose legacies of a differentiated racial regime. In this regard, we take up the trajectory of racialisation as in its segregationist and apartheid modalities of state formation; its deracialisation in our post-apartheid modality of social engagement towards the non-racial project of constitutional democracy as a movement beyond the shadow of racist thinking both implicit and explicit. The thrust of our engagement is that in order to make sense of racial formations and their modalities of structural orientation and social agency we need to think of racism within the complex of a state-race-class nexus. In sum then, the argument that we make vis-à-vis the differentiated racialised orders is that we need to embed ourselves within our national, South African, and continental, African, contexts in order to challenge the racial traditions that continue to bedevil efforts towards consolidating our constitutional democracy and its concomitant epistemic project.
\end{abstract}

Keywords: developmental state, racial formations, higher education institutions, democracy, South Africa. 


\section{Introduction}

Historically, in South Africa, racial imperatives were deeply embedded in the institutional processes of the segregationist and apartheid states. Today, despite the social initiatives of the state in the period following the birth of democracy, South African society and its institutions continue to be racially wired. The prefix 'post' in 'post-apartheid' signals, at one and the same time, that the contemporary South African state is beyond the legal and political strictures of the past order, and that the present social order is replete with overdeterminations by preexisting racial formations, in all areas of social life. Democratic transformation has set in motion a process through which the various racialised layers of social action and interaction forged under the segregationist and apartheid orders are being successively peeled off. However, it should come as no surprise that the deepest layers of social life, those concerned with the conscious and unconscious predilections of knowledge production, should be among the last of the excavations of racialised sites that need to take place. It is argued here that it is no accident or quirk of history that higher education arrives late, for in this archaeological site where the racial formation is being excavated we are necessarily dealing with some of the deepest-set bedrock assumptions and metaphysical principles which underpin social life.

\section{Theoretical Problematic}

The Ministerial Report of 2008/9 has thrown into sharp relief how deeply embedded is race in the social relations and structures of higher education. In the face of reform initiatives by the current state that aim to negate the previous racial order, what might be defined as the recalcitrance of established structures in higher education suggests that - in the words of the Report - the existing racial legacy may be 'more intractable' than at first believed.

At the heart of the vexed question of the relationship between the current developmentalist state and preexisting racial formations is the issue of the continuities and discontinuities in contemporary South Africa. This paper seeks to theorise this relationship, along with the way in which it is commonly represented and the kinds of social agency it proscribes, at the point where it manifests itself as a social phenomenon in higher education. What is problematic about contemporary discourse is that race and racism are presented as a uniform discourse without any inflections. We are confronted with racism as an homogenous entity, which permits the most bald-faced racism to be accentuated to such an extent that it's more subtle forms disappear from view.

In order to adumbrate the more complex and subtle forms of racism a theoretical language is required, one which provides a way to examine race without assigning to it a validity predicated on scientific legitimation. At the same time it is necessary to 
avoid focusing too intently on the pseudo-scientific nature of race, lest racism itself disappears from view. The theoretical problem, then, is to develop a discursive modality that is able to both give credence to the lived reality of racism and simultaneously expound upon its many nuances and inflections without essentialising any of them. Goldberg's (2002) theoretical perspective offers just such an interpretive framework. His concept of racial formation provides a way to talk about racism as something socially constructed, while his account of the racial traditions that attach to racial formation, namely, the racial naturalist and racial historicist modalities of social agency, makes it possible to understand the nuances within both the segregationist and the apartheid racial formations.

A primary theoretical task is how to disentangle racial formations in their most subtle and overt forms from the discourse of development translated as deracialisation and non-racialism. In some of the racial formations currently manifested in the academy, blacks remain in a state of perpetual tutelage, always having one or other mentor imposed upon them, and never capable in and of themselves. What is most insidious about this discourse is that it is constructed as developmentalist and progressive, thus occluding the racial historicist tradition in which it is embedded.

In the process of briefly outlining Goldberg's (2002) theoretical framework, this paper presents an argument for seeing race not as an epiphenomenon but as a structural condition. In so doing it makes specific reference to the historical continuities and discontinuities of racial formations in the political economy of South Africa, from its emergence as a qualified nation-state in 1910, under a segregationist state and its social agency within a racial historicist tradition, through the apartheid state and its shift from a racial naturalist to a racial historicist tradition, culminating in the present conjuncture characterized by a developmental state in a constitutional democracy in which non-racial and anti-racist social agencies are moving the racial formation towards a class formation.

For the purposes of the discussion which follows, the term 'race' is to be understood as the 'face' of social class relations. While race is always part of a race-class nexus, involving complex and dynamic intersections and interrelationships, this paper analytically isolates the element of race, in order to highlight features which are too often repressed in recent South African scholarship on higher education.

\section{Race as Structural Condition}

\section{The State-Race Nexus}

Under what conditions might one legitimately speak about 'race', as a structural condition, when the very concept is subject to contestation at its foundational level, that is, at the level of its ontological status? Moreover, how is 'race' to be understood in relation to 
the emergence of the modern state, higher education and the socio-political project of nation building? These questions relate to the structural relationship we seek to draw between the state, race, higher education and post-apartheid South Africa. The argument here is that 'race' is not some superimposition grafted onto the nation-state, nor is it to be reduced to the affliction of any individual member of society. Rather, the underlying structure giving coherence and definition to the configuration of state, race, higher education and transformation is the broader socio-historical process of modernization. The starting point, then, is to establish the discursive intersection between the modern state and 'race' before setting it in the context of the new South Africa and higher education from the point of view of its structural orientation and social agency.

Drawing on the work of Jewsiewicki and Mudimbe (1995), Goldberg (2002:130) argues that in the same way that states instrumentally invent races as a form of generalized socialization, they invent nations:

States instrumentally invent nations as a form of generalized socialization. By the same token, states are instrumental in inventing races both as form of socialization and as technologies of control.

The aforementioned process of inventing nations and 'races', is not entirely an arbitrary one. The conditions under which discourses of the nation and 'race' emerge in relation to modern states are such that:

They do not create races artificially from whole cloth, however, but pick up the threads for designing the racial fabric from various sources, scientific and social, legal and cultural.

In qualifying the inventive process associated with the nation and 'race', Goldberg (2002) moves from a rather unidirectional isomorphic relationship posited between the state and 'race' (whereby state invents race) to a concept foregrounding a dialectical relationship between them. Wider social structures and their relations come to bear on the process of fabricating or inventing nation and 'race'. Most importantly, it is through the dialectic between the modern state and the individual that emergent forms of nation and 'race' are produced. As McCrone (1998) put it, 'nation/race is the meeting point between the State and the individual'.

Nation and race, fabricated by states out of various scientific, social, legal and cultural threads, are at the heart of socialization, and socialization is at the core of social structure. The extent to which states weave race into the social fabric of society is also an indication of the degree to which the modern state itself is fashioned with racially woven threads. 
States then are fundamental to weaving race into the social fabric, and indeed the fabric of the modern state is fashioned with racially woven threads. States thus are endowed or endow themselves with "races" [Sic]; they adjust and adopt races to governmental purposes.

Taking it one step further Goldberg infers, in a dialectical turn of logic, that:

While states are instrumental in the institutional conceptualization of races, racial conceptions define and refine state formation (Goldberg, 2002: 131).

On this basis, it is argued here that state and 'race' are involved in a deeply embedded structural relationship which constrains social agency in defined ways. It is useful to explore, in the following section, the import of this relationship for understanding the political economy of South Africa, with particular reference to whether and how arguments around continuities and discontinuities between the segregationist and apartheid states and racial formations are relevant to the shift from apartheid to postapartheid society.

\section{The Race-Class Nexus: South African Dynamics}

The early 1970s debate between Wolpe (1972) and Legassick (1975) over the relationship between racial formations and capitalist development offers a number of insights relevant to a better understanding of the continuity and/or discontinuity of racial formations. Arguing for continuity between the segregationist and the apartheid state, ${ }^{1}$ Legassick (1975:261, cited in Motala, 2006:8) suggested that the racial division of labour and attendant coercive mechanisms in the nascent mining industry were extended - hence, continuity - to the manufacturing economy which prevailed under apartheid. In contrast to this, Wolpe (1972, cited in Motala, 2006) argued for discontinuity in the sense that the electoral victory of apartheid signaled that the capitalist mode of production had finally prevailed over African pre-capitalist modes of production.

From the vantage point of the state inscribed as a racial formation, it can be argued that the subsidiary position occupied by the African communal modalities in relation to the European capitalist mode, and their dissolution and absorption into the social relations of wage labour, served as the structured historical conditionality of 'super exploitation' or the production of ultra-cheap labour. The costs of the social reproduction of African labour was considered - and effectively enforced - to be much lower than that of their white counterparts. The point here is not about cheap labour per se - for all labour is cheap (Morris, 1977 cited in Motala, 2006) - but rather that cheap labour

1 The literature on the South African state spans the liberal (Lipton, 1986) and radical (Wolpe, 1972, 1988; Legassick, 1974; Davies et al, 1976; Alexander 1979, 2002; Posel, 1991; Motala, 2006) divide. 
is located at the very heart of the production of surplus value, with the state assumed to be neutral in the relationship of classes (Wolpe, 1972). Thus the continuity between the segregationist and the apartheid states is premised on the structural embeddedness of the racial formation of African labour in the very heart of the economy, at the point of capitalist production itself. In turn, this is the basis for the argument in this paper that that race is not an epiphenomenon but a structural condition stitched into the social fabric of society with its concomitant modalities of racial historicist and naturalist traditions of social agency. In the political economy of South Africa, race and class merge and as such form a nexus.

\section{Racial Naturalist and Racial Historicist Traditions of Racial Formations}

Goldberg's (2002) discussion of what is referred to here as the social reach of the discourse of 'race', in the form of its two traditions, namely, naturalist and historicist, usefully illustrates the scope of agency against the backdrop of racial structural constraints. In terms of the "racial naturalist" conception, in some European and wider processes of state formation - especially those where, as in South Africa, coercion was a key instrument of state unification - the resulting state was likely to be more prone to a naturalist conception of racial formation, with racial rule considered as the product of a divine hand or Nature (Goldberg, 2002:74).

By contrast, the "racial historicist" conception is linked to a different modality of state formation, where states growing out of financial centers and founded predominantly on capital formation and circulation - such as in England or France - tended in the course of their development to have inscribed in their bureaucracies the presumption that racial rule is an outcome of history, an historically produced superiority (Goldberg, 2002:74).

Goldberg's (2002) account thus draws a distinction between a political imperative in state formation, namely, the coercive state (the authoritarian-apartheid state), and an economic imperative particularly in capital-based state formations (also referred to as the liberal state). This corresponds in a non-deterministic manner to 'racial naturalism' and 'racial historicism', respectively. The 'overdetermination' of the political in racial states is a necessary outcome of the coercion required to effect and maintain law and order against resistance by the racialised Other. The social dynamic of the economic dimension of social life expressed categorically as class relations in Europe was also cast in a racist discourse, as evident in the exclusion of the working class in earlier discourses of nation-state formation in Europe (Goldberg, 2002). 


\section{Traditions of Racial Formations and Social Agency}

The implications of 'racial naturalism' for social agency, both collectively and at the level of the individual in relation to the coercive nature of the state, translates into an environment which was particularly restrictive for the 'racialised Other' across a wide spectrum of social relations and hierarchies which are fixed and endow their members with an ascribed status from which there is no exit. 'Racial historicism' allows for the passage of the racialised subject from infantilism to maturity within a developmental paradigm, whereas 'racial naturalism' holds the subject forever in the vice grip of an 'infantile disorder'. It is important to note that both traditions share a common social horizon insofar as both wish to produce social "homogeneity" (Goldberg, 2002). In both naturalism and historicism homogeneity is represented by a European norm vis-à-vis colonialism, either politically as racial rule (white and capitalist) or as an economic model (European and capitalist).

The foreclosure of social agency with respect to naturalism, then, refers to a delimitation of race into one that is not transmutable, while historicism opens up the possibility of becoming modern for those 'developing' states and their citizens. In addition, racial naturalism coupled to coercive states positions social agents as racial outsiders which in effect means that transformative action is directed against the hostile racial state by 'non-citizens' apparently outside of the nation-state structure (the liberation movements in South Africa are a case in point). In racial historicism, on the other hand, social agency is undertaken by citizens of potential citizens from within the system and within a framework of modernization and development.

Finally, for Goldberg all racial states are engaged in the constitution, maintenance and management of whiteness in different forms: European domination, colonialism, segregation, white supremacy, herrenvolk democracy, Aryanism or ultimately even colour blindness (i.e., racelessness). The term "whiteness refers to a structural condition and is not meant to fix absolutely and disrespectfully in privileged and racist place subject positions of persons classified as white" (Goldberg, 2002:195). In other words, race shapes social life in as much as the social conditions fashion racial arrangements (Goldberg,2002:195). Whiteness stands socially for status and superiority, politically for power and control, economically for privilege and property, culturally for self-assertion and arrogance, and also dialectically for anxiety and a crisis in confidence (Goldberg, 2002:195). It is on the basis of this brief account of the intersection between state, nation, race and class - the state-race nexus, in short - that we wish now to probe the social and institutional imperatives of higher education. 


\section{The Social Context and Institutional Imperatives of Higher Education}

Considered as an institutional and social problematic, the transformation of higher education in South Africa can be seen as an attempted shift from an apartheid racial formation to a deracialised social formation or, in other words, to a non-racial institutional order. Of fundamental importance is the extent to which the apartheid logic in the organisation of the higher education system has been disrupted by the sensibilities of the new state, informed as it is by a constitutional democratic dispensation.

\section{Social Context and Racial Formations}

In the post-apartheid period, what can be identified in institutions of higher education in South Africa, and particularly in English-speaking, historically white universities is not necessarily a national discursive formation as such, but the slippage from the particular to the quasi-'universal'. One encounters a supra-national discursive formation referred to as Western thought or Eurocentrism, which acts as a substitute for contextual embedding in a national context. In other words, in this ontological grounding outside of the national formation, in the West, lies the will to escape the racialised context of knowledge production that characterized apartheid South Africa. The supreme paradox is that the flight to the West does nothing more than render even more pronounced the very racial embedding that is taken for granted in epistemologically privileging European thought. The pursuit of the status of 'world class university' is for all intents and purposes another case of the Western idiographic (or the particular, i.e., Europe) passing itself off as the nomothetic (or the universal).

The immediate relevance of the prefix 'post-'in 'post-apartheid' is that, while illustrative of the social fact that the apartheid state is no longer a legal entity, it nevertheless, like its use in postmodernism or postfordism, also signals that one is not quite far enough beyond apartheid to be able to signify a new social modality except to point to certain tendencies and movements. Of equal relevance, 'post-' as in postfordism and postapartheid also connotes that what it precedes has achieved both intensive and extensive social 'penetration'. For example, Fordist techniques of production have been applied not only to a range of industries but also to multinational food corporations (Ritzer, 1997); similarly, the term 'post-apartheid' invokes the connotation that South African society is both intensively and extensively a racial formation. This is the structural orientation of the racial formations of the apartheid state through which the social categories of class and gender were expressed as lived realities. 


\section{Political Dimensions of Higher Education: Views From the Top}

Discontinuities in the racial formations as manifested under apartheid can be represented by the three Presidents of the constitutional democracy, each of whom have made (and are making) their mark on society in various ways. First, the presidency of Mandela was defined by a symbolism that was predicated upon the newly opened space for the political agency of citizenship. This form of social agency seems to fit with neither of Goldberg's racial traditions (naturalist and historicist), but instead heralds the sociopolitical conditions for the possibility of a deracialised and non-racial social formation. However, the racial legacy permeates our society and as such we need to be theoretically vigilant. To this end, the discontinuity with the racial formation of the past was symbolically realized through reconciliation so as to grasp the new future endearingly referred to as building the new South Africa.

So as to obviate any confusion or conflation between the racial historicist tradition and the nation-building project, i.e. reconstruction and development, it must be made clear that the constitutional democratic content of the developmentalist state is not oriented towards the racialisation of South Africa in any form, black or white. Under the first democratic Minister of Education, Bhengu, we witness the suturing in of new foundational values and principles such as equity and redress (as opposed to the earlier inequitable racial legacies) as well as legislation in the form of the Education White Paper of 1997 and the Higher Education Act of the same year. This opened up a new type of social agency which is neither of the racial naturalist type (a truncated agency) nor of the racial historicist tradition (as perpetual tutelage), but instead a social agency that speaks to the potentiality of a pedagogic subject socialized in the foundational values and principles of democratic access and citizenship in the context of an African Renaissance. The White Paper of 1997 foregrounded questions of equity, access and redress as a means of transforming the reproductive function of higher education, insofar as it no longer serves a racial project but instead a national project with an African continental sensibility.

Second, the presidency of Mbeki was distinguished by the provisioning of a coherent framework for building the nation predicated on African-centeredness and ideologically anchored in modernization and development (Freund 2004:43). In this regard Mbeki opened up the conceptual space of the developmental state to allow for a new set of regional and continental articulations, and in particular sought to break the disarticulation of South Africa from the rest of Africa which had been produced under the racial naturalist period of apartheid known as baaskap. At the same time it sought to redress the racial historicist tradition, most manifest during the phase known as separate development, when the Bantustans emerged as a response to the African decolonization wave. These necessary correctives to both the racial traditions made possible that form of 
social agency described as the African Renaissance. It is also in this context of Africancentredness that the racial historicist tradition of social agency becomes distanced from state policy and re-located amongst those in the academies pursuing a Eurocentric agenda tout court and thus inadvertently perpetuating the racial formations.

Third and finally, while it is too early to make any firm predictions about the presidency of Zuma, one emerging feature is the consolidation of the developmental state as a key mechanism for steering reforms related to the economically marginalized sections of society (such as the poor, unemployed youth and agricultural workers). In a corresponding process, the new Minister of Higher Education and Training, Nzimande, is placing greater emphasis on access, widening the system, rural development and articulating education with labour market imperatives. This suggests that higher education will be placed in greater service to the economy and society in general. However, the initiatives under Minister Nzimande, particularly with respect to the envisaged plans to expand higher education into rural areas, also reveal a greater contextual embedding in the national project of democratizing access to higher education. This is not merely a spatial dynamic aimed at restoring the underdevelopment of the rural areas in the face of an urban bias, but a challenge to the rural/urban division itself to the extent to which it was closely tied to the logic of capital accumulation under the aegis of the apartheid state.

What this amounts to, in terms of a distinction between deracialisation and nonracialism or anti-racism, is that all three of these presidencies have had to deal with the structural features of apartheid and to confront how these continue to operate in post-apartheid society. While in spirit or ethos we align ourselves to constitutional democracy, in reality we are still confined to the adumbration of apartheid and hence it is more appropriate to speak of post-apartheid in the sense of the project still being one of deracialisation.

\section{Institutional Imperatives of Higher Education: Racial Formations and Social Agency}

\section{Higher Education Landscape and Racial Traditions: 1910-2010}

This section offers a periodisation of higher education in relation to Goldberg's two racial traditions, both as they articulate with the three presidencies indicated above and in the light of the institutional imperatives that higher education confronts in the contemporary period.

At the behest of the segregationist state, and against the backdrop of early industrialization, all historically white colleges, forged through the underlying conflicts between the two political elects of British and Afrikaner nationalism, were granted university status. This occurred in the context of a framework premised on a qualified 
concept of nationhood. It is important to note that, in higher education during this period, class stratification was overlaid with that of race. The South African Native College was not granted university status; in other words, it was not allowed to formally affiliate with the then examining body in the same way as its white counterparts. The College nevertheless became a training ground for many African leaders, suggesting that its social function with respect to the African population was the production and reproduction of a very small African intelligentsia. Traces of a racial historicist tradition are evident, insofar as the local population would be placed on a modernization path. To put it bluntly, under the dispensation of the segregationist state the 'native subject would be civilized' by being located on a linear modernizing trajectory of development, with the implicit though deferred assumption that at some future point there would be an equivalence between the 'native' subject as 'civilized' and the white counterpart.

With the advent of the apartheid state, following the victory of the Nationalist Party in 1948 , an expansion of the higher education sector initiated under racial and ethnic policies saw the emergence of historically white and mainly Afrikaans-medium universities (with the exception of the University of Port Elizabeth as a dual medium university) at the same time as the promulgation of the Education Extension Act of 1959 marked the establishment of the first coloured and Indian universities as well as rurally-located black universities balkanized on the basis of supposed ethno-linguistic communities.

The apartheid period reveals imbrications of both of Goldberg's racial traditions. In terms of the overt racist framing of the racial naturalist tradition, the black subject in all its gradations (African, coloured and Indian) was positioned as a political outsider, with limited social agency. This was most evident during the baaskap or white supremacist introductory phase of the apartheid state. However, with the emergence of the phase of separate development we witness a shift from a racial naturalist to a racial historicist tradition. This can be attributed to recognition that the black subject was capable of political leadership within his/her own domain, a possibility foreclosed in the first phase of apartheid. Arguably, it was the context of African decolonization that prompted apartheid thinking to acknowledge the social agency of Africans as early potential citizens, albeit under the tutelage of the white state and in the circumscribed space of the Bantustans. It is in this political context that we should understand the emergence of African universities as a function of the need to create an intelligentsia to staff the bureaucracies of these quasi-states.

The demise of the apartheid state and the emergence of a constitutional democracy has been accompanied by the restructuring of the higher education landscape so as to reflect the emerging and more integrated nation. Particularly pertinent here is the process through which existing higher education institutions have been merged. This reconfiguration of the higher education sector inevitably imported the racial traditions associated with both the segregationist and the apartheid state, with their different modalities of social agency. In such a context, the racial historicist tradition is easily able 
to masquerade as a developmental discourse aimed at redress, and this in turn impacts directly upon the intellectual division of labour and how it plays itself out in terms of racial formations and the system of stratification.

The racial historicist tradition treats black subjects as potential candidates for development and excellence, and at the same time assumes that white subjects embody excellence and are, in virtue of their whiteness, quite competent. The developmental discourse seeks to go beyond this (and arguably all) racial formations, by embodying subjects and social agency in terms of an African Renaissance. In other words, it aspires not to reach white standards but instead to achieve African excellence.

To the extent to which South African universities operate in accordance with Eurocentric norms, they constitute black subjects as, at best, racial historicist subjects or, at worst, as racial naturalist subjects. In both cases it remains within the adumbration of a racial formation - and is clearly racist to boot. While the deracialising merger process initiated by the state was confronted with huge disparities between institutions and their constituents, within institutions there remain articulations of racial formations that are still continuous with the past. In the process of merging, some of these institutions, essentially racist in Goldberg's sense of racial naturalism, have had to reckon with their own ideological baggage, and challenges of this sort still burst through from time to time, as evidenced in the University of the Free State's "Reitz incident". Other institutions, however, often in the top rank of the institutional type and embedded in a racial historicist tradition with its accompanying paternalistic attitude, have not met with any institutional reconfiguration and have been left largely intact. Paradoxically, the challenges in these institutions to confront the racial formations embedded in their institutional logic are greater than those for whom racism was an explicit form of conduct, largely because the racial historicist tradition blurs in relation to the developmental discourse, to the extent that what was previously an identifiably racialised dispensation might now be considered progressive.

\section{Social Accountability and Reification: Intervention, Autonomy and Social Agency}

The issue of the social accountability of higher education institutions is sometimes portrayed as if it involves an isomorphic and unidirectional relationship, where the university is accountable to the state. The reverse, however, where the state is accountable to higher education institutions, is also important, for not only should the universities give account of what they do in relation to their social mandate, but equally so, the state must give an account of its social mandate with regard to its role in the universities. State intervention in higher education is sometimes seen as peculiar to the constitutional democratic state and, moreover, to the South African context, but these perceptions are in need of correction. The reach of the apartheid state into the universities, in terms of faculty appointments, student enrolments and academic content, was both decisive and 
debilitating. The racial formation of apartheid, namely, white exclusivity, was influential in determining the demographic character of white institutions, while in relation to the epistemic project it was debilitating inasmuch as radical scholarship was effectively banned from these institutions. It should come as a great surprise to anyone attuned to the legacy of the racial formation of the apartheid state that scholars of supposed note find it difficult to reconcile themselves with the university's alignment with the society's national project.

However, the immense social scale that is involved in the transformation of higher education institutions (a process that cannot occur independently of other social institutions) suggests that the type of state associated with a minimalist social role as favoured by neo-liberal theory would be inappropriate. An expanded space must be opened up for the role of the state, in contradistinction to the retreatism of the neoliberal state and its social diminution. In the light of this, the developmentalist state, acting in terms of its social mandate, seeks to bring all institutions into its orbit and under a single governance system. This is intended to reverse the havoc that the racial formations and both its traditions have wreaked upon society. To argue that it is not in the best interests of higher education to align itself with this progressive cause is to take flight from society and succumb to the delusion that, somehow, universities under apartheid were autonomous.

The higher education system is still imprinted with the differentiated forms of control characteristic of apartheid, which ranged from direct control (most often in the case of black institutions) to more indirect forms of intervention. Today, this differentiation fosters resistance to transformation, with, for example, the principle of relative autonomy which oriented white institutions under apartheid now being stretched, under the new order, in the direction of almost absolute autonomy, with the converse being the case for formerly black institutions. Considered against the 'reracialisation thesis' (Sayed and Soudien, 2004), one cannot help but be wary of the success of the transformative project in the light of the institutional autonomy and academic freedom that higher education institutions enjoy. There is indeed a very fine line between too much state direction, which undermines the epistemological project, and unfettered institutional autonomy, which makes possible the drawing up of laagers and its attendant racial exclusivity.

\section{Equity, Racial Formations and Deracialisation}

\section{Enrolments}

One way of determining whether the higher education system has gone beyond its apartheid racial formation, is by asking quantitative questions, such as whether the composition of students and faculty reflect a deracialised patterning. With regard to the 
composition of student enrolment, there has been an overall increase in the number of black students in the higher education system (Ntshoe, 2003). While recognizing that statistics can be made to tell many stories from different vantage points, the magnitude of the increase of black students in general and of African students in particular is strong evidence for a discontinuity between the present and the preceding racial formation of apartheid society. This is corroborated by juxtaposing the findings of the Council on Higher Education (CHE, 2004) with respect to headcount enrolments in 1999, against data from the South African Race Relations Survey of 1989. In 1989, out of a total enrolment figure of 380789 , black and white enrolments constituted $43 \%$ and $57 \%$ respectively, with the former broken down into 29\% African, 7\% Coloured and 7\% Indian. By contrast, in 1999, with a total enrolment figure of 566 000, the proportion of black to white enrolments was $71 \%$ and $29 \%$ respectively, of which the former comprised 59\% African, 5\% Coloured and 7\% Indian.

In order to bring these figures into Goldberg's (2002) framework of racial formations, it is necessary to establish how the demographic breakdown at the universities compares with that of the total population. This helps to establish whether the universities are becoming more representative of the national population and as such are being deracialised. Towards this end, in 1989, out of a total national population of 36 million, the breakdown as per racial formations was 75\% African, 3\% Asian, 8\% Coloured and $14 \%$ White; in 1999, out of a total population of 43.3 million, the breakdown as per racial formations was 77\% African, 3\% Asian, 9\% Coloured and 11\% White.

In order to establish some kind of understanding of these figures, namely that of higher education enrolments, we have opted to juxtapose these against the racial formations as represented in the demographic make-up of the South African population as a whole. Despite the fact that this juxtaposition is somewhat of an oversimplification of actual participation rates across racial formations insofar as these do not take account of the demographic structure of each racial formation group and how this in turn relates to participation, the point here is not about participation rates per se but about how racial formations are situated in relation to the political imperative of constitutional democracy which is ostensibly about the unmaking of such formations.

Considering the fact that representation of black students as a racial formation in higher education in 1989 was $43 \%$ of the total student enrolment, this translates into $86 \%$ of the corresponding racial formation in the total population in South Africa. By contrast, the same proportionate relationship of black students as a percentage of the total student enrolments is $71 \%$, which constitutes $89 \%$ of the corresponding racial formation in the total population in the country.

Of the total student enrolment, the percentage of black students in higher education as cited above was $43 \%$, increasing by $28 \%$ to $71 \%$ in 1999 . How does this $28 \%$ increase reflect nationally in terms of the dimension involved in the distribution of racial formations in the total population of the country, or in other words, can this increase 
be treated as an indication of deracialisation, thus representing a break with the racial formation of the past? When higher education enrolments and the racial formations and their corresponding breakdown in the population of South Africa are drawn together, a significant relationship emerges, which helps to establish the dimensions involved in the deracialisation of racial formation.

In 1989 the proportionate figure of black higher education enrolments and its relation to the black racial formation as an expression of the total population of South Africa was $50 \%$ (i.e. $43 \%$ of black enrolment in higher education measured against the $86 \%$ of black representation in the national population). In 1999, black student enrolments comprised $71 \%$ of total enrolments, which when compared to the corresponding racial formations of the total population of South Africa of $89 \%$ results in a proportionate relationship of $80 \%$ (i.e., $71 \%$ of black enrolment in higher education in relation to the $89 \%$ of black representation in the national population). Leaving aside the statistical merits of such a comparison, in absolute terms the movement at the level of black representivity in higher education is marked by a significant difference (from 50\% to 80\%). This clearly suggests that deracialisation is taking place and that the apartheid racist project has been disrupted.

These figures are important for an additional reason, namely that they represent the potential for class formation, inasmuch as they are predisposed towards the production and reproduction of the intelligentsia and are thus linked towards middle class formation. The issue of class formation is fundamentally about deracialisation and as such represents the mechanism for undoing the racist project of apartheid. However, the deracialisation project in relation to its class dimension does not merely rest at the level of student enrolments; more importantly, this class project is only consummated in the form of successful throughputs at both undergraduate and postgraduate levels. Furthermore, the class project is only realized in the form of a meaningful engagement in the economy through employment, for throughput is not an end in itself. The critical issue here in relation to the matter of continuity and discontinuity in racial formations is that where the throughput rate falls short of expected outcomes, one is not significantly altering the racial formation even though, at the level of enrolments themselves, this might suggest a move towards deracialisation.

Having identified a deracialisation project (or a post-apartheid social moment) in the demographic shifts in student enrolments as they relate to the national population, and having concluded that this process can only be consummated when it reaches the critical mass of a class formation (or a constitutional democratic moment) that no longer carries the markers of an apartheid social architecture, we turn now to the matter of deracialisation as an epistemic project. An epistemic intervention is critical in that it involves the contextualization of the academic project and the extent to which it is embedded in the national and continental formations. The articulation of Afrocentrism and Eurocentrism at the behest of the former is precisely the difference between a racial historicist construction of social agency and one that moves outside the adumbration 
of the logic of racial formations and embraces a non-racial and anti-racist sensibility. Baldly stated, the emphasis on Eurocentric modalities to the virtual exclusion of an Afrocentric sensibility in the academic project, masquerading by proxy in notions of academic excellence, standards, autonomy and globalization, are merely versions of the racist underpinnings of racial historicist views.

Emphasising Afrocentrism to the point of excluding Eurocentrism would be equally foolhardy. The issue, rather, is the logic of its articulation in the international dimensions of the academic project in particular and the intellectual project in general. The common criticism of Africanisation, that it is a nationalistic and essentialised project, reveals traces of a sublimated racial naturalist orientation which tends towards the erasure of Africa and its relationship to modalities of knowledge formation. Furthermore, it is a testimony to the decontextualisation of higher education from its national context that the national formation has within this structure not appeared as an epistemic formation in the construction of curricula that are in an organic relation to the context. Instead, there is an over reliance on Eurocentric and Western texts in general in the curricula of academia without any recognition of the irony involved.

\section{The Academic Profession}

Goldberg's (2002) concept of racial formations and its traditions alerts one to the manner in which subtle forms of racism disappear from view when constructed in the idea of a developmental discourse and progress. It is important to note that this analysis of racial formations does not have white racism as its sole focus. There is no conspiracy theory under construction here. Rather, racism must be dealt with in whatever form it takes and particularly in its manifestation in the academy. The intellectual division of labour in the higher education system is generally acknowledged to reflect fairly sharply the racial formations of apartheid inasmuch as these represented white domination. The point is not that academics that have the structural position of whiteness and have also acquired professional academic experience, skills and expertise have nothing to offer aspirant black academics. Instead, the intellectual division of labour is predicated on racial formations and to overlook this fundamental social and political feature of South African society is to both reinforce and legitimate and justify the racial historicist tradition and thus racism in such a guise.

Of equal importance is that Goldberg's (2002) work gives credence to and recognizes the lived experiences of people who encounter the social relations of racism in their daily professional lives. After all, to paraphrase Marx, the point is not only to interpret the world, but to change it, and this in turn requires recognizing that racism in South Africa is much more than a contentious and controversial issue requiring further analysis - it must also be combated. To fail to tackle racism head on is to head in the direction of 
erasure or amnesia, and leads to denialism and avoidance.

The demographic transformation of academia in the direction of greater racial equity and representivity is merely the tip of the iceberg. A more substantive transformation is required within the core activity of higher education institutions, namely in knowledge production and dissemination. Unfortunately, racial historicist fears that increasing the number of black academics will result in a reduction in standards and excellence ignore the fact that what diversity brings to the epistemic formation is not merely a change in the profile of the producers of knowledge but rather in the very shape and complexity of that knowledge formation.

In other words, for as long as knowledge production continues to be anchored in and dominated by one section of society, academia will continue to produce knowledge that is partial and one-sided, leaving much of the complexity of society untouched. Unlike the deracialising trend in student enrolments and demographics, staff demographics continue to remain skewed. Indeed, in this regard one might speak of the converse of a deracialisation project and continuity with the racial formations of apartheid. Black faculty at the Universities of Cape Town, Stellenbosch, Rhodes, Free State and the Witwatersrand constitute only 23\%, 16\%, 17\%, 19\% and 29\% of staff, respectively (DoE, Annual Report 2009).

Migdal (2001) has argued that change in the institutional culture of higher education rests at the margins, meaning that it is through the appointment of new faculty that cultural change is registered. This position is reinforced by Mannheim's view (1956:175) which holds that:

The physiognomy of a culture changes when the strata actively participating in cultural life, either as creators or as recipients become broader and more inclusive.

It follows that, in the South African academic context, an institutional culture and its modalities of knowledge production can be said to stand or fall with the extent of deracialisation and diversification. Failure to transform at this demographic level, that is, to deracialise, is not merely a superficial bean-counting matter, but speaks to the relevance and significance of the core practices of our institutions of higher education. Where transformation is not in evidence, one might question whether in fact academic excellence can be said to be present. Young Turks of all hues, but especially those from the black racial formation, offer the universities their best chance at epistemic transformation and with it a non-racial and non-sexist future.

\section{Conclusion}

This paper has argued not only that racial formations are structurally embedded in racial states (segregationist and apartheid), but that the most obdurate forms of racial 
embeddedness are still sutured into the social fabric of society. To speak of racelessness in a post-racial state is to make 'whiteness invisible' as social value and as norm, and is tantamount to returning to the discursive silences and trepidation that discourses on 'race' invoke as social taboo.

For as long as the present is only defined by a modern sensibility in the adumbration of a European/white racial formation, it will remain within the racial historicist tradition of social agency. In order to move beyond racial historicism, the question of deracialisation and its non-racial project has to be contextualized and embedded in an Africanist formation beyond 'race' or 'colour' but nevertheless predicated on a commitment to the transformation of the epistemic formations of academia. The challenge is to reconcile Afrocentrism with Eurocentrism, and for this purpose it may be necessary, as Lash (1990) argues, to appropriate the sociological imperative of postmodernism, which is to "dedifferentiate" difference.

The logic of dedifferentiation is not about indulging in the denial of lived realities such as racial formations, but in taking the prejudice and bigotry out of such differences. Whether an individual chooses to be identified through some racial formation is a different matter from whether there is a structural orientation which facilitates a social agency predisposed to racism. Put differently, racial formations need to be transformed from their present hierarchical structure into more laterally organized forms, and this process can be assisted, in academia, by a shift from forms of mentorship and tutorship predicated upon subtle forms of racism embedded in the racial historicist tradition, to forms which are anchored in a developmental logic and a non-racial sensibility. It seems pointless to speak of a social state in which there is no 'racial' awareness per se; such awareness depends rather on the social content that informs such a concept.

At bottom, what is required is a subtle shift from the notion of a post-apartheid state (one concerned with deracialisation) to a constitutional democratic state proper (one concerned instead with non-racialism, or even anti-racism). In this latter configuration what one should expect to see is an effacement of race in both the race-class nexus and the state-race nexus, resulting ultimately in a state-class nexus. Whether this in turn is in fact the most desirable state remains an open question, but what is beyond contestation is that both the post-apartheid and the constitutional democracy scenarios must be embedded in a logic of articulation of Afrocentrism and Eurocentrism, though most importantly guided by the former. 


\section{Bibliography}

Anthias, F. and N. Yuvil-Davis. 1992. Racialized Boundaries. London: Routledge.

Council on Higher Education, 2004. South African Higher Education in the First Decade of Democracy. Pretoria: Council on Higher Education.

Department of Education, 1997. Education White Paper: A Programme for the Transformation of Higher Education, Pretoria.

Freund, B. 2004. South Africa: A New Nation State in a Globalizing Era. Transformation 56: $1-52$.

Goldberg, D. T. 2002. The Racial State. Oxford: Blackwell.

Lash, S. 1990 Sociology of Postmodernism, New York, Routledge.

Legassick, M. 1975. South Africa: Forced Labour, Industrialisation and Racial Differentiation. In The Political Economy of Africa, ed. R. Harris. Boston: Schenkman.

Mannheim, K. 1956. Essays on the Sociology of Culture. London: Routledge and Kegan Paul.

Marx, K. 1954. Capital, Vol. 1. London: Lawrence \& Wishart.

McCrone, D. 1998. The Sociology of Nationalism. London: Routledge.

Migdal, J.S. 2001. State in Society. New York: Cambridge University Press.

Ministry of Education, 2008 Report of the Ministerial Committee on Transformation and Social Cohesion and the Elimination of Discrimination in Public Higher Education Institutions, Pretoria.

Motala, E. 2006. State Analysis: Its importance to theory, critique and practice: The case of the Apartheid State. Unpublished paper.

Ntshoe, I. 2003. The political economy of access and equitable allocation of resources to higher education. International Journal of Higher Education Development 23: 381-398.

Ritzer, G. 1997 Postmodern Social Theory, New York, McGraw-Hill.

South African Institute of Race Relations, 1990. Race Relations Survey 1989/90, South African Institute of Race Relations, Johannesburg.

South African Institute of Race Relations, 1995. Race Relations Survey 1994/95, South African Institute of Race Relations, Johannesburg.

Soudien, C. and Sayed, Y. (2004) A New Racial State? Exclusion and Inclusion in Education Policy and Practices in South Africa, in Perspectives in Education, 22 (4):101-116

Wolpe, H. 1972. Capitalism and Cheap Labour Power in South Africa: from segregation to apartheid. Economy and Society, 1(4).

On line access http://www.statssa.gov.za/publications/SAInTransition/

$\underline{\text { SAInTransition1999.pdf }}$ 